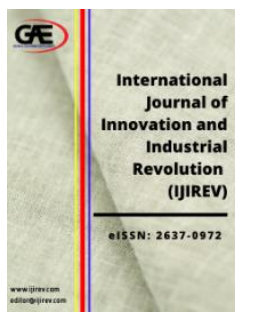

\author{
INTERNATIONAL JOURNAL OF \\ INNOVATION AND \\ INDUSTRIAL REVOLUTION \\ (IJIREV) \\ www.ijirev.com
}

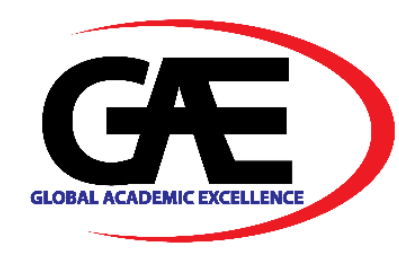

\title{
INDUSTRIAL REVOLUTIONS AND SHIFTING OF GLOBAL COMPETITIVENESS
}

\author{
Thilanka Baratha Dewanarayana $^{1}$, Wijitapure Wimalaratana ${ }^{2}$ \\ 1 School of Business, National Institute of Business Management, Colombo 07 \\ Email: barathadewanarayana@gmail.com \\ 2 Department of Economics, Faculty of Arts, University of Colombo \\ Email:wimala10@gmail.com
}

\section{Article Info:}

Article history:

Received date: 21.01 .2021

Revised date: 30.01 .2021

Accepted date: 27.05.2021

Published date: 15.06 .2021

\section{To cite this document:}

Dewanarayana, $\mathrm{T}$. B., \& Wimalaratana, W. (2021), Industrial Revolutions and Shifting of Global Competitiveness. International Journal of Innovation and Industrial Revolution, 3 (7), 19-30.

DOI: $10.35631 /$ IJIREV.37003

This work is licensed under $\underline{\mathrm{CC} B Y} \mathbf{4 . 0}$ (c)

\section{Abstract:}

Industrial revolutions marked rapid structural transformation in the manufacturing sector making changes to production processors and products while reshaping the lifestyle across the world. Industrial revolutions redefined the product identity of every individual economy with the changes of specializations acquired through different manufacturing sectors. Similarly, new sets of countries emerged as industrial input providers as well as output buyers. At the same time, the world specialization in the manufacturing sector diversified along with the expansion of global value chains. As a result, the final product is assembled in one location while a multitude of components is produced globally by different countries. The intention of the article is to examine the shift of global competitiveness throughout the last two decades with the emergence of the Fourth Industrial Revolutionary implications especially among Developed Economies and Newly Industrial Economies. The international competitiveness of a country is mainly decided by the relative cost of production. The relative cost is again decided by the productivity, availability of quality resources including labor, cost of doing business, favourable macroeconomic factors, and institutional factors. The main objective of this study is to focus the attention on the reshaping of the global competitiveness map along the timeline as a result of technological spikes known as industrial revolutions paying special attention to the fourth industrial revolution. The secondary sources are tapped for the necessary information and mixed-method is applied to analyze the gathered data. The implications of the fourth industrial revolution show the reshaping of the global competitiveness landscape faster than the previous industrial revolutions. Countries with more commercialized innovations, intellectual property rights, and adopting key technologies such as artificial intelligence, big data analytics, the internet of things, cloud computing, 3D printing, and simulations in production are at the forefront of the competitiveness in the manufacturing sector. 


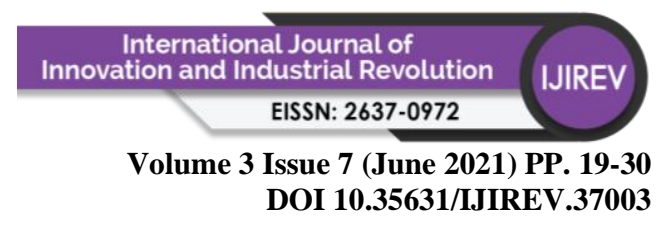

Keywords:

Industrial Revolutions, Competitiveness, Macroeconomic Indicators, Industrial Policies

\section{Introduction}

Industrial revolutions are considered as turning points in the manufacturing sector making changes to production processors and products while making a huge impact to the lifestyle across the world. Industrial revolutions, among many others, redefined the trajectory of product specialization of every individual economy in the world paying the way for new division of the factors of production including the labour. The global division of labour and specialization were redefined as industrialized countries and primary product exporting countries. The global trade diversion and the creation were visible along with the industrial revolutions. New value chains emerged, some of the old value chains either the disappeared or replaced with new/amended chains reflecting the changing global economic contours. Along the timeline of industrialization backed by industrial revolutions, the final industrial product is a result of an assembled object from the components of different.

International product competitiveness of a country is mainly decided by the relative cost of production. The relative cost is again decided by the productivity, availability of quality resources including labour, cost of doing business, favourable macroeconomic factors and institutional factors. The historical global case studies suggest that the degree of global competitiveness in terms of manufacturing value additive (MVA) was shifting from the west to the east of the world in the past. This will continue further, and the Asian continent is going to be the economic powerhouse in the middle of this century, so that they are suggesting this would be the Asian Century in the world (Huiyao, Wang 2019). The manufacturing sector gradually expanded in Newly Industrialized Countries (NICs) as well as in developing countries drawing new contours in the global manufacturing map.

\section{Objectives}

The main objective of the study is to focus the dimensions of reshaping the direction and mode of global competitiveness map in line with technological spikes while paying special attention to the fourth industrial revolution. To identifying contributory factors of global competitiveness is the secondary objective of the study.

\section{Methodology}

The secondary data sources are tapped for the data collection aligning with research objectives. The mixed method was used for the analysis depending on quantitative and qualitative secondary data on the global competitiveness. The scope of the study is confined to impact driven by the fourth industrial revolution on the global competitiveness of economies as per indices used to measure the global competitiveness. The Secondary Data backed by the Global Competitiveness Index (2019) in terms of Regional and Country Analysis - Pillar wise Changes in Regional Performance 2018-2019, The Economist, Intelligence Unit report -2018 and other empirical literature.

\section{Literature Review}




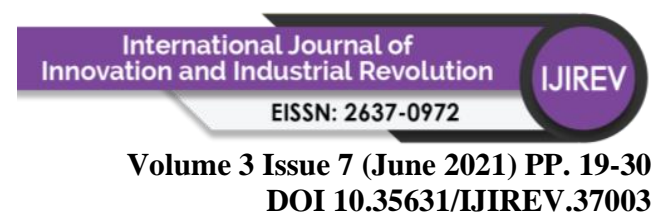

\section{Pre-Industrial Revolutions and Global Competitiveness}

The first industrial revolution or the first wave of industrialization made significant improvements in the textile industry in Britain. Haradhan, (2019) mentioned that Textile industry as a heart of the industrial revolution and Britain became the "workshop of the world" during the period. Cotton textile industry reported persistent growth in England starting from 1770 and contributed $40 \%$ of the world cotton goods within the Manchester. Britain was reputed for clothing the world with the expansion of textile industry with the support of its colonies as well. The number of power looms in England increased rapidly as 12,150 to 85,000 in between 1820 to 1833 while increasing employment from 800,000 to $1,500,000$ in mid $18^{\text {th }}$ century. The led the expansion of American cotton production from 1.5 million pounds to 85 million pounds in 1810 with cotton imports to England. Britain iron and steel production has extensively increased from 28,000 tons to 250,000 tons during 1750 to 1805 with the imports from Russia and Sweden. Glass, soap and paper industries in addition to textile were also major during the industrialization due to massive production of chemicals such as sulphuric, hydrochloric acid, sodium carbonate sodium sulphate etc.

The Second industrial revolution is also termed as technological revolution and marked shift in global competitiveness by diverted a portion of the second industrial revolution towards United States of America (USA) with the American inventions relating to electricity such as internal combustion engine, telegraph, telephone and radio, chemical, transportation including cars and oil industry etc. Haradhan, (2020)

Third industrial revolution or the internet networking revolution brought radical up down changes for both production and consumption decisions at large. Worldwide web (www) minimized transaction cost while allowing nations to re-distribute the degree of global competitiveness in proportionate with the ability to adopt changes. As per the indications it was the USA where the first computer has been built. Later the developments of information technology spread across the globe while challenging the level of global competitiveness based on various goods and services being provided to reshape the mode of production and the consumption.

\section{Global Competitiveness}

As Ruixia, .X et.al, (2012) quoted Porter .M.E, (1990) "competitiveness as the one of central preoccupations of industry and government of each nation". In addition, Lall, .S, (2001) says that the most of the policy makers pay considerable attention on national competitiveness. Some nations succeed and others fail due to hard working in identifying and creating national competitiveness at the global edge (Ruixia, .X et.al, (2012). The Irish National Competitiveness Council (1997) defines the competitiveness as the ability of firms to compete in markets. The Competitiveness Framework Review, (2016) by the National Competitiveness Council of Irish identifies the different characteristics of competitiveness. Initially competitiveness was defined with respect to location's unit cost level as a capability to compete successfully in global markets and location's productivity level causing to enhancements of standards of living of individuals. According to World Economic Forum, (2010) the national competitiveness refers to "the set of institutions, policies and factors that determine the level of productivity of a country". Liu, C, (2017) also presented views on definitions and interrelation of competitiveness and industrial revolutions. Liu, C, (2017) quoted Delgado et al.,(2012) also confirmed the definition of Irish Competitiveness Council. Industrial revolutions were based 


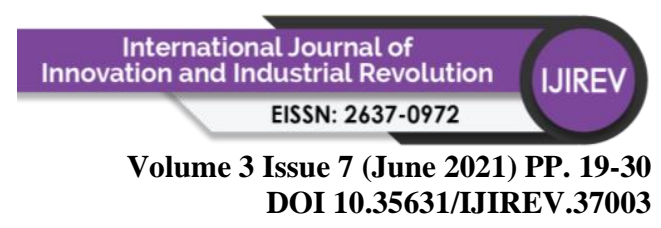

on competitiveness of nations and as an example the competitiveness owned by US in 1980s were challenged by rise of international competitiveness of Japan. Competitiveness is also defined at industry and firm level as well. But those were also defined with respect to cost and productivity aspects as in the case of national level to bring benefits to the given economy. Liu, .C:2017; Bhawsar \& Chattopadhyay: 2015; Cho \& Moon: 2013) confirmed the 'absolute advantage theory" by Adam Smith, "comparative advantage theory" by David Ricardian and "Heckscher - Ohlin theory" by Heckscher and Ohlin to elaborate the competitiveness as a concept. In addition, the technology gap theory of International Trade and product life cycle theory are also used to explain the competitiveness. Portor's, (1990) Diamond Model, Three Competitiveness Dimensions by Buckley, Pass and Prescott, (1992), Assets -Processors Performances (APP) Model by Ajitabh and Momaya, (2004), Three Sources of Firm's Competitiveness by $\mathrm{Ma}$ and Liao, (2006) were also discussed in literature to review competitiveness in a wider manner. Determinants of the competitiveness were recognized at micro and macro levels as well. (Liu, .C, 2017)

Global competitiveness has been a popular concept for scholars for various objectives. The purpose of this explanation is to ascertain how nations built their own identities while influencing the degree of global competitiveness.

\section{Trends in Global Competitiveness}

The Global Competitiveness Report, (2019) stated that the globalization and the fourth industrial revolution were the key determinants of opportunity creation for economies and polarization in between economies in the world. Global Competitive Index ranked Singapore as the most competitive economy in the world. United States, Hong Kong SAR, Netherlands, Switzerland, Japan, Sweden, UK and Denmark were ranked as the top nine competitive economies after Singapore at that order.

Kate, .W, (2019) of World Economic Forum announced the world's ten most innovative economies in October 2019 report. In descending order, Germany was at the top during the year and it was followed by United States, Switzerland, Taiwan, and China, Sweden, South Korea, Japan, United Kingdom, France and Netherland based on the Global Competitiveness Report. Germany was selected to the top on the list due to high marks for research and development backed by higher number of patent applications per million of population. The merits of the United States to stand at the second place was the higher number of scientific research papers publications. Switzerland became the second most innovative nation in the Europe which was strongly backed by its high skilled workforce. Taiwan and China reached the Fourth position being third highest for patent applications per million of population and workforce diversity. Sweden at fifth position is significant for investment of research and development account for 3.3\% of GDP for promoting innovations. South Korea came to the sixth position as it was the second most innovative economy in Asia. In addition to the, South Korea was at the top position for buyer Sophistication and second the highest for patent applications and investment on research and development to promote innovations. Japan was at the seventh position due to topping the list for investment on research and development. United Kingdom was standing at the eighth position due to its strong position on scientific publications. France and Netherlands became ninth and tenth positions respectively due to being the third for the degree of recognition of research institutions and overall improvement of all indicators of research and development sub pillar while ranking at the third for multi stakeholder collaboration. 


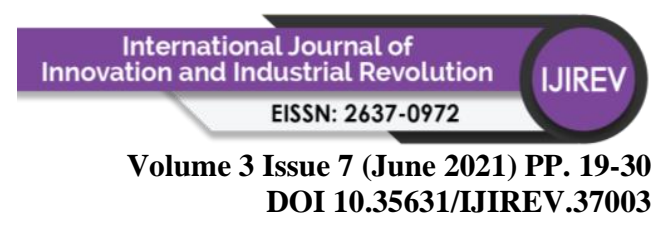

\section{Contributory Factors of Global Competitiveness}

Narula \& Wakelin, (1995) clearly mentioned the existence of developing countries at the global trade depend on transformation of industrial structure throughout the period, commercial and technological expertise of nations leading to innovations. The competitiveness of a country is usually reflected by the economic growth rate of a country led by the increase of productivity of production processors and growth patterns of export composition while generating considerable foreign currency income and employment opportunities by confirming the national identity in terms of comparative advantage (Lall, 2001). Further it was mentioned in the literature that the process of globalization caused to change nature of functions at international markets while changing hierarchies of the same. However, changes due to technological advancements caused to affect the shape of industries and trade by reshaping the nature of international firms. More specifically technology intensive production was prioritized to enhance the output share at the global market while creating employments to manage the competitiveness (Aharoni \& Hirsch, 1997).

Economies such as Singapore, South Korea and Hong-Kong strongly revealed the correlation between economical richness and technological advantages-based competitiveness; where Philippine, Thailand and Indonesia revealed the same as relatively less evidence. (Uchida \& Cook, 2005) Especially countries like South Korea and Taiwan utilized technological advancements in their domestic firms in the industrialization process where Malaysia and Thailand were in the process of increasing the low cost and skilled based exports with the purpose of allowing export of high-tech components. India as one of the largest economies focused on utilizing technology in local aspects especially in terms of computer programs by encouraging technology for local consumption led local industries. (Kumarswamy et al, 2012) Countries could develop their own technologies in identified aspects of manufacturing of various products and services positioned themselves as emerging economies in the world and made a significant effect to the process of global competitiveness. Brazil specialized in aircraft, electronics and computers, Malaysia in terms of electronics and India in computers in the process of influencing the global competitiveness. Certain developments of nations witness the adaptation of imported technologies and combined efforts for customizing and upgrading in a local aspect as the strategy of developing the competitiveness. According to Luo et al, (2011) the same has been shown with respect to BRICs as well. India and China were strong in ICT industries while showing strong capabilities in making graduates and professionals in the field of engineering, technology and computer science as an input for those ICT related industries. Russia made the advantage of manufacturing of high-tech defence related items to the world.

\section{Measurements of Global Competitiveness}

Literature and related theoretical aspects reveal various measurements for the global competitiveness. The study mainly focuses on Global Competitiveness Index and the Automation Readiness Index while paying attention to other areas where necessary. The components of the indices cover a range of dimensions for the purpose of ranking countries. It was understood that the rankings differ as the dimensions and weight given.

\section{Global Competitiveness Index (GCI)}




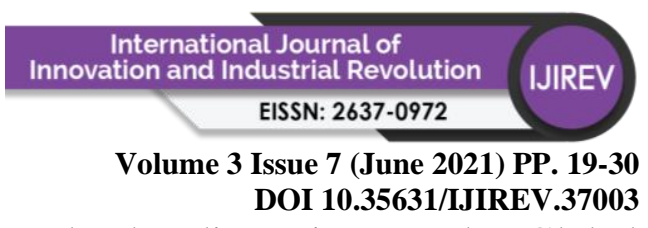

The fundamental changes take place in economies made the discussion on the Global Competitiveness Index 4.0 and recommended certain characteristics to be practiced to avoid challenges and risks possible to associate with. As per the said recommendations economy (i) should be resilient- to be ready to use economic mechanisms to avoid financial crises and heavy unemployment issues due to external issues, (ii) should be agile - to adopt and implement changes as in the form of advantages to the nation and applying them in newest production of goods and services, (iii) should be an Innovative ecosystem - innovations should be appreciated and awarded at all the levels in order to encourage the emergence of new ideas and facilitated with financial and commercial aspects and finally (iv) should be human centric - should understand the significance of human involvement for creating prosperity by proper utilization of human capital to ensure better living conditions. The Global competitiveness Index 4.0 has arranged on twelve (12) pillars which were constructed on the said four (04) concepts. (Global Competitiveness Report; 2018)

\section{The Automation Readiness Index (ARI)}

The Automation readiness Index is to measure the level of preparedness of a country for upcoming intelligent automation wave with the Fourth Industrial Revolution. The index is about 25 countries regarding ongoing government led initiations to welcome and absorb forecasted results due to changes and to redesign the outcomes due to technological advancements. In other words, the index is a snapshot of selected 25 countries as said above. The study behind the index focuses on possible changes for next twenty to thirty years as how human activities are expected to be aligned with upcoming automation technologies in both socio and economic aspects. The index includes G20 countries, and five more countries represent diverse regions of the world. The index benchmarking model is based on 52 quantitative as well as qualitative indicators surveyed in research. The rankings shown in Figure 01 are based on The Economist, Intelligence Unit report 2018. 


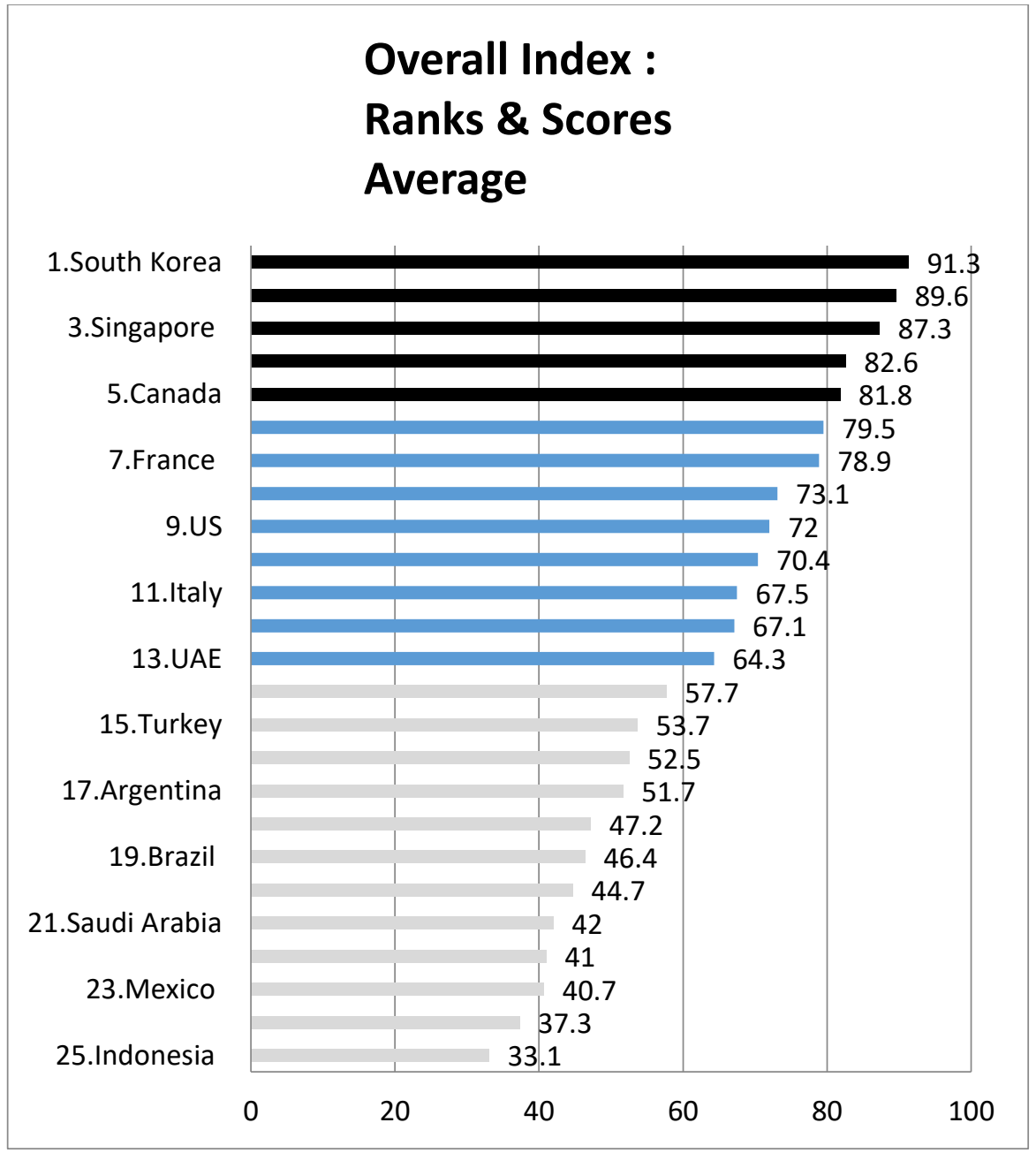

Figure 1. Automation Readiness Index -2018 Source: The Economist Intelligence Unit Limited, (2018)

\section{Fourth Industrial Revolution and Global Competition}

Turel, M.,Akis, E, (2019) was in the opinion that the Fourth Industrial Revolution as the reason for the transformation of global production from West to the East of the world; was also confirmed by Khan, Turowski, (2016). Countries like China, Indonesia and other developing Asian countries were able to attract most popular brands depending on relatively less labor as an advantage while influencing the position of the global competitiveness. Further the findings of Roland Berger, (2014) shown that the Western Europe lost $10 \%$ of Value-Added Production in traditional manufacturing industries. It was also noted the forecasts relating to the Fourth Industrial Revolution correlated with global competitiveness in the near future; the forecasts were the number of robots usage in industry as expected 3 million and connected devices are expected to be 29 billion in 2018; the expected market size of internet of things would be USD 1.7 trillion in 2020 and in 2025 the manufacturing process of developed economies would be based on automation at a rate of $15 \%-25 \%$. (Turel, .M \& Akis, .E, 2019)

As per the views of Bartodziej, (2016) the manufacturing industry has been affected for structural change due to the Fourth Industrial Revolution. The inventions and practices redefined the modern life connected with high technology products with the listed components 


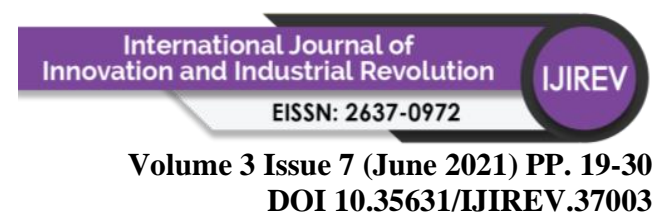

below; Wireless networks with data, computational power and connectivity, artificially intelligent objects, augmented reality with developed man machine interactions and emergence of 3D printing. Mahdawi, (2017) mentioned creation of employment opportunities in USA and UK from $2001-2015$ as approximately 3.5 Million due to the digitalization and automation as a result of the Third Industrial Revolution and increasing the level of automation has caused to lose approximately 800,000 jobs in USA with the origin of the Fourth Industrial Revolution.

\section{Industrial Sector and Manufacturing Value Added (\% of GDP)}

The figure below indicates the way that the global competitiveness is positioning from 2005 to 2013 in terms of automation percentage of selected countries with respect to 'Manufacturing Value Added (\% of GDP) where China, Germany and Japan were in the front.

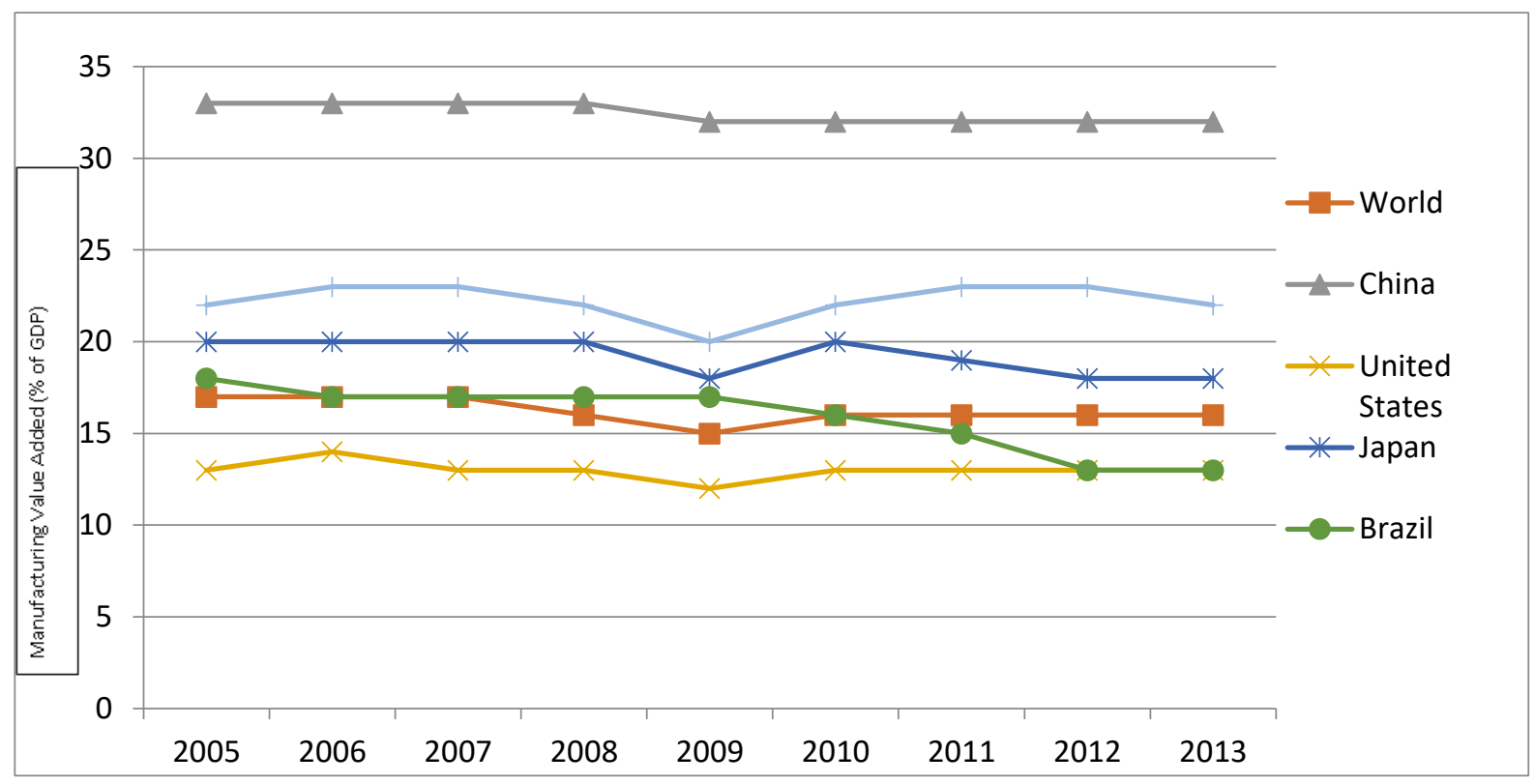

Figure 2. Automation Percentage for Countries. Source: World Bank 2015

Dachin,. A, (2006) explained the way that the "Manufacturing Value Added (\% of GDP)" has changed from 1990 -2003 in the different segment of the world while affecting the position of global competitiveness basically focusing on the Third Industrial Revolution started from 1960 onwards.

Table 1 Manufacturing Value Added - World MVA

\begin{tabular}{lrrr}
\hline & $\mathbf{1 9 9 0}$ & $\mathbf{2 0 0 3}$ & $\begin{array}{r}\text { Changes in the share } \\
\text { of world MVA }\end{array}$ \\
\hline Industrial Countries of which: & 84.4 & 76.2 & -8.2 \\
& & & \\
EU (15) & 30.5 & 26.3 & -4.2 \\
Countries in transition & 5.6 & 3.2 & -2.4 \\
Japan & 22.5 & 17.9 & -4.6 \\
North America & 22.5 & 25.7 & 3.2 \\
\hline
\end{tabular}




\begin{tabular}{|c|c|c|c|}
\hline & & Innova & $\begin{array}{l}\text { ternational Journal of } \\
\text { on and Industrial Revolution }\end{array}$ \\
\hline & & & EISSN: $2637-0972$ \\
\hline & & & $\begin{array}{l}\text { olume } 3 \text { Issue } 7 \text { (June 2021) PP. 19-30 } \\
\text { DOI 10.35631/IJIREV.37003 }\end{array}$ \\
\hline & 1990 & 2003 & $\begin{array}{c}\text { Changes in the share } \\
\text { of world MVA }\end{array}$ \\
\hline Developing countries of which: & 15.6 & 23.8 & 8.2 \\
\hline NICs & 8.6 & 10.8 & 2.2 \\
\hline Second generation of NICs & 2.5 & 3.6 & 1.1 \\
\hline China & 2.2 & 6.5 & 4.3 \\
\hline
\end{tabular}

Source: International Yearbook of Industrial Statistics 2004, UNIDO, Vienna.

Manufacturing Value Added (MVA) of industrialized countries decreased by $8.2 \%$ and developing countries were able to increase their MVA in parallel but industrialized countries could dominate the global manufacturing further. China as a separate country has shown a significant improvement by $4.3 \%$ throughout the period. Even though there was a reduction of MVA the structural changes of manufacturing towards medium and high technologies in MVA was properly managed and therefore the increase of technology composition was reflected by industrialized economies from 1980 to 2000 approximately from $55.4 \%$ to $60.3 \%$. Developing economies could also follow the same pattern from $40.8 \%$ to $52.9 \%$ during the same period as it was shown in the Industrial Development Report in 2004. Literature reviewed that Republic Korea and Taiwan province of China by that time were successful in transformation of production and export structures and started moving towards advanced industrial countries. Developing countries were able to increase the export performances during the period by $7.3 \%$ where industrialized countries lowered the same by $7.2 \%$ in terms of their market share Most of the developing countries performed well in terms of skilled based and technological products and the specialty was that some countries could position themselves among top 25 high technology product exporters in the world. Singapore $-5^{\text {th }}$, Taiwan Province of China $-7^{\text {th }}$, Republic of Korea $-8^{\text {th }}$, China $-9^{\text {th }}$, Malaysia $-9^{\text {th }}$, Mexico $-12^{\text {th }}$, Philippines $-16^{\text {th }}$, Thailand $18^{\text {th }}$ and Hungary $-25^{\text {th }}$ positions respectively as per the Industrial Development Report, UNIDO, (2004). With the price of labor and labor intensive production strategies developing countries were trying to be in line with industrialized economies were positively backed by the massive populations and to create new markets domestically in the countries like China and India.

\section{Intellectual Property (IP)}

The contemporary global production and trade leadership has been critically characterized by the ownership of intellectual property rights including patents, utility models, trademarks and industrial designs. As indicated by the World Intellectual property Indicators, (2019) China was identified at the highest contribution to the global growth in intellectual property fillings in recent years. China accounts for patents $(+11.6 \%)$, trademarks $(+28.3 \%)$ and industrial designs $(+12.7)$ growth rates in 2018. In addition, China owns more than half of global trademarks and industrial designs as $51.4 \%$ and $54 \%$ respectively. The ownership of patent fillings accounts for approximately $46.4 \%$ globally. The statistics below clears the shift of global competitiveness with the effects of the fourth industrial revolution. 


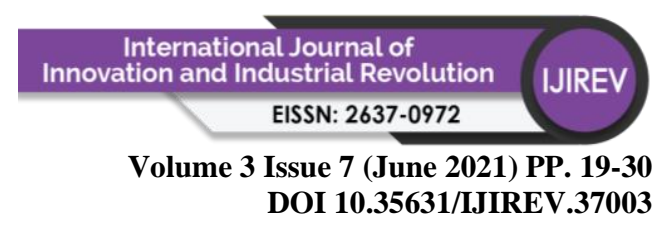

New Directions of Global Competitiveness

The global competitive directions have changed along with the industrial revolutions. And this section focuses on new directions of the global competitiveness in the light of Global Competitive Index

Apart from Europe and North American economies, the economies in the East Asian and Pacific Region have shown a significant developments in the fields of product market, market size and financial markets and being competitive with Europe and North America. The Global competitiveness Report, (2019) confimrs that the ICT adoptions contributed 1.3 points improvement in the overall global competitiveness year on year and witness with growths in all the regions. In addition financial systems and skills sub pillars also depicts overall growth in all the regions. Business Dynamism also reveals overall growths in all the regions except Eurrasia.

Table 2 Regional Performances by the Pillar

\begin{tabular}{|c|c|c|c|c|c|c|c|c|c|c|c|c|}
\hline \multirow[b]{2}{*}{ Region } & \multicolumn{4}{|c|}{ Enabling Environment } & \multicolumn{2}{|c|}{$\begin{array}{l}\text { Human } \\
\text { Capital }\end{array}$} & \multicolumn{4}{|c|}{ Markets } & \multicolumn{2}{|c|}{$\begin{array}{l}\text { Innovation } \\
\text { Ecosystem }\end{array}$} \\
\hline & 总 & 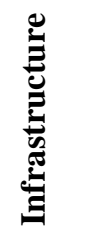 & 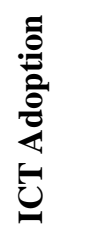 & 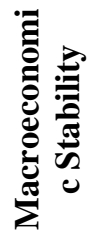 & 吾 & $\stackrel{n}{\overline{\bar{n}}}$ & 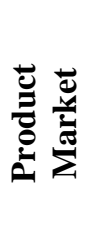 & 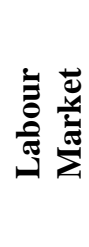 & 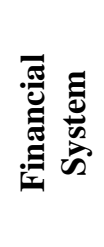 & 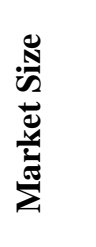 & 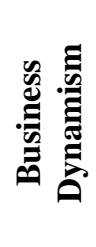 & 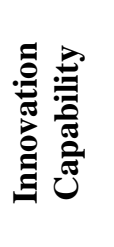 \\
\hline $\begin{array}{l}\text { East Asia } \\
\text { and the } \\
\text { Pacific }\end{array}$ & 61.6 & 74.8 & 70.3 & 89.6 & 83.8 & 67.3 & 62.2 & 66.6 & 74.3 & 67.9 & 66.1 & 54.0 \\
\hline $\begin{array}{l}\text { Europe } \\
\text { and North } \\
\text { America }\end{array}$ & 64.7 & 79.7 & 70.4 & 92.6 & 89.1 & 74.6 & 60.0 & 66.4 & 70.9 & 60.1 & 68.3 & 58.1 \\
\hline Eurasia & 53.8 & 67.7 & 59.5 & 74.9 & 71.3 & 66.1 & 56.1 & 63.5 & 52.0 & 50.3 & 61.9 & 35.5 \\
\hline $\begin{array}{l}\text { Latin } \\
\text { America } \\
\text { and the } \\
\text { Caribbean }\end{array}$ & 47.1 & 61.3 & 50.9 & 73.7 & 82.2 & 58.7 & 51.6 & 55.9 & 60.3 & 51.2 & 53.8 & 34.3 \\
\hline $\begin{array}{l}\text { Middle } \\
\text { East and } \\
\text { North } \\
\text { America }\end{array}$ & 55.5 & 70.5 & 57.6 & 75.3 & 80.8 & 62.9 & 56.7 & 54.8 & 63.7 & 59.9 & 58.2 & 41.3 \\
\hline $\begin{array}{l}\text { South } \\
\text { Asia }\end{array}$ & 50.0 & 59.2 & 35.1 & 74.7 & 68.4 & 50.1 & 45.8 & 51.5 & 60.0 & 67.7 & 57.8 & 36.3 \\
\hline $\begin{array}{l}\text { Sub } \\
\text { Saharan } \\
\text { Africa }\end{array}$ & 46.9 & 45.0 & 34.3 & 69.4 & 50.8 & 44.3 & 49.3 & 54.6 & 50.8 & 40.4 & 51.8 & 29.4 \\
\hline
\end{tabular}

Source: World Economic Forum Analysis, Global Competitiveness Report, 2019 


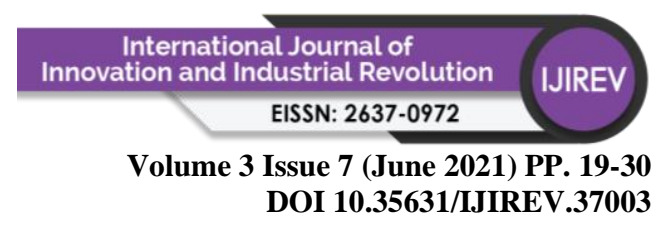

\section{Conclusion}

The implications of the fourth industrial revolutions show the reshaping of global competitiveness landscape faster than the previous industrial revolutions. Countries with more commercialized innovations, intellectual property rights and adopting key technologies such as artificial intelligence, big data analytics, internet of things, cloud computing, 3D printing and simulations in production are at the forefront of the competitiveness in manufacturing sector. The increase of service sector performance throughout the world confirms the expansion of sophisticated technological production and consumption. The overall growth in ICT Adoption and Skill sub pillars as depicted in Global Competitiveness Index ensures the application of fourth industrial revolutions and its potential expansion further. The increasing trend of the total employment percentage in service sector and decreasing trends in agricultural sector provides the nature of the global competitiveness in next few years to come. Intellectual Property (IP) determines the ownership of the global competitiveness during the era of fourth industrial revolution. China being in the top of the lists in terms of patent, trademark and industrial designs ownership by drawing its massive boundary in the global competitiveness. However, in terms of degree of automation the China is positioned in $12^{\text {th }}$ where South Korea, Germany, Singapore, Japan, Canada, Estonia, France, UK, USA, Australia and Italy ranked at the ascending manner as per the Automation Readiness Index, (2018).

Economies in the East Asian and Pacific Region have shown a significant developments in the fields of product market, market size and financial markets and being competitive with Europe and North America due to the enhanced competitiveness led by Singapore being the most competitive economy. The relative global competitiveness of Honkong SAR being $3^{\text {rd }}$ and Japan being $6^{\text {th }}$ positions. But still economies such as Cambodia and Lao PDR being $106^{\text {th }}$ and $113^{\text {th }}$ respectively reflect deficits of global competitivenss too. The overall $2^{\text {nd }}$ position of global competitivenss of United States contributes to lead Europe and North America being home for Innovation capability and Business Dynamism. The global competitiveness positions of member economies in the region such as Genrmany, Netherlands, Switzerland, Denmark, United Kingdom and Sweden make the ambience more competitive.

\section{References}

Aharoni, .Y \& Hirsch, .S, (1997), Enhancing competitive advantaged in technological intensive industries, In: Dunning, J.H.,Hamdani, K.A (Eds), The New Globalism and Developing countries. United Nations University Press, Tokio, NY, Paris, pp. 260-302

Christian Ketels, (2016), An Analysis Conducted for the National Competitiveness Council, Competitiveness Framework Review, National Competitiveness Council, Dublin

Delgado .M, Porter .M.E, \& Stern .S, (2012), The determinants of national competitiveness (NBER Working paper No 18249)

Department of Economic and Social Affairs, (2017), The Impact on the technological revolution on labor market and income distribution, Frontier Issues

Haradhan Kumar Mohajan, (2019), The First Industrial revolution: Creation of New Global Human Era, Journal of Social Sciences and Humanities, Vol. 5, No. 4, 2019,pp 377387

Haradhan Kumar Mohajan, (2020), The Second Industrial has Brought Modern Social and Economic Developments, Journal of Social Sciences and Humanities. Vol. 6, No. 1, 2020,pp 1-14

Klaus Schwab, (2019), The Global Competitiveness Report, Insight Report, World Economic Forum 


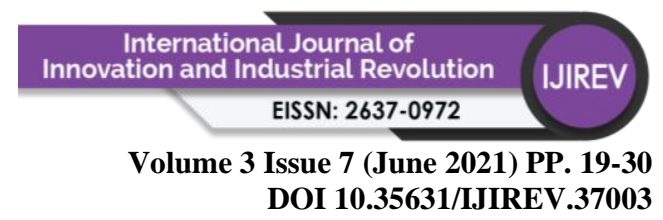

Koc, T., Teker, S., (2019), Industrial Revolutions and its effects on quality of life, Press Academia Procedia (PAP), V.9, p.304-311

Kumaraswamy, .A, Mudambi, .R, Saranga, .H \& Tripathy, .A, (2012), Catch-up strategies in the Indian auto components industry: domestic firm's responses to market liberalization. Journal of International Business Studies 43

Lall .S, (2001), Competitiveness indices and developing countries: an economic evaluation of the global competitiveness report, World Development, Vol.29, No.9, pp.1501-1525

Liu .C, (2017), International Competitiveness and the Fourth Industrial Revolution, Entrepreneurial Business and Economics Review, 5(4), 111-133

Ma .N \& Liao .M, (2006), A Firm -level study of the international competitiveness: Theoretical analysis and empirical findings, International Journal of Innovation and technology management, 3(1), 21-41

Narula, .R \& Wakelin, .K, (1995), Technological competitiveness, trade and foreign direct investment

Pragya Bhawsar \& Utpal Chattopadhyay,(2015), Competitiveness: Review, Reflections and Direction, Global Business Review - July 2015

Roland Berger, (2014), Industry 4.0- The new industrial revolution- How Europe will succeed. Roland Berger Strategy Consultants

Ruixia Xia, Tao Liang, Yali Zhang \& Sibin Wu, (2012), Is global competitive index a good standard to measure economic growth? A suggestion for improvement, Int. J. Services and Standards, Vol 8, No. 1, 2012

The Economist Intelligence Unit Limited,(2018), The Automation Readiness Index, Who is ready for the coming wave of automation

Tofler, .A, (1981), The Third Wave, London: Pan Books Ltd

Turel, .M \& Akis, .E, (2019), Industry 4.0 and competitiveness, Research Journal of Business Management (RJBM), V.6 (3), p.204-2012

Uchida, .Y \& Cook, .P, (2005), The transformation of competitive advantage in East Asia: an analysis of technological and trade specialization. World Development 33 (5), 701-728.

World Intellectual Property Organization, (2019), World Intellectual Property Indicators, ISBN: 978-92-805-3094-0 